\title{
BUILDING A NETWORK CONCEPT IN CONTEMPORARY PUBLIC ADMINISTRATION
}

\author{
Khuriyatul Husna \\ PhD Candidate at the Department of Public Policy and Management \\ Faculty of Social and Political Sciences Universitas Gadjah Mada \\ Address: Jalan Socio Yusticia No. 1, Bulaksumur, \\ Yogyakarta 55281, Indonesia \\ E-mail: khuriyatul.husna@mail.ugm.ac.id
}

\section{Bevaola Kusumasari}

Head of Doctoral Program, Department of Public Policy and Management Faculty of Social and Political Sciences, Universitas Gadjah Mada, Indonesia. Email: bevaola@ugm.ac.id (Corresponding Author)

\section{Agus Pramusinto}

Professor and Head of the Department of Public Policy and Management Faculty of Social and Political Sciences, Universitas Gadjah Mada, Indonesia. Email: aguspramusinto@ugm.ac.id

\begin{abstract}
This study aims to provide an overview of the literature on network research that developed in public administration studies over a period of ten years (2007-2016). Besides this, it also observes whether a consensus on the network concept was reached among scholars during this time period. The differences in approaches and perspectives used by public administration scholars in understanding networks each have their own implications on the heterogeneity of network research. Such differences, hence, influence the way they define networks. The rise in the amount of research and differences in the use of the "term" network indicates that clarity in the network concept has yet to be reached. The contribution of this study is based on the fact that the field of public administration needs to be more aware of the network literature in other disciplines and to employ this research to advance the understanding of network issues in the public sector context.
\end{abstract}

Keywords: Public Administration; Network; Stream Network; Fragmentation concepts.

Citation: Husna, Kh., Kusumasari, B. \& Pramusinto, A. (2019). Building a Network Concept in Contemporary Public Administration. Public Administration Issue, Special Issue I (electronic edition), pp. 46-61 (in English); DOI: 10.17323/1999-5431-2019-0-5-46-61. 


\section{Introduction}

Research on networks, which has progressed steadily in public administration studies, is ongoing and depends substantially on enhanced clarity of the concepts and definition of networks (Lecy, Mergel \& Schmitz, 2014, p. 657). "All science depends on its concepts" (Sir George Thomson, 1961, p. 4), and "we live in a conceptual world" (Bogason \& Toonen, 1998, p. 211).

In fact, research on networks in public administration has developed so rapidly that Agranoff and McGuire consider today to be the "age of networks" (2001, p. 677).

However, this development has not been supported by a clearer understanding of the concept of networks in public administration. It has been observed that a "coherent body of scholarship on networks has not been developed and common understanding of what networks are, has not been reached" (Wachhaus, 2009, p. 60).

In order to further understand the concept of networks, it has been suggested that scholars periodically "organize" the literature systematically (Lecy et al., 2014). Wachhaus (2009) conducted a survey of network literature from 1986 to 2006 and offered seven attributes that may be used as a baseline definition of networks: complex, exchange, interaction, interdependency, nonhierarchical, governance, and policy.

Isett et al. (2011) divided network research into three streams: policy, governance, and collaborative networks. Similarly, Lecy et al. (2014) clustered research networks into three categories: policy formation, governance, and policy implementation networks. Although the two groups of authors reached similar conclusions, the concept of networks remains fragmented and inconsistent, as observed in previous studies (Blom-Hansen, 1997; Borzel, 1998; Damgaard, 2006; Hall \& O'Toole, 2002, 2004). Based on the findings of Wachhaus (2009), Isett et al. (2011), and Lecy et al., (2014) on the development of the concept of networks in public administration studies, it is imperative that scholars maintain a focus on this development.

This study intends to thoroughly examine variations in network research during the period of 2007-2016. This article provides an overview of networks in public administration research and intends to establish that the concept remains fragmented and that there is as yet no consensus on the understanding of networks. This assumption (epistemological) is established on the basis that public administration initially emerged as an art rather than a science wherein its advent was a necessity for resolving practical matters, and in fact there was debate on whether it was art or science between Simon and Waldo in addition to discussion on defining the concept of "publicness", which remains unclear today (Udo Pesch, 2005).

Public administration has developed by adopting theories from other scientific disciplines, and the concept of networks is also utilized based on researchers' needs (Agranoff, 2007; Wachhaus, 2009).

This article is divided into 4 parts. The first part contains the research background and objective. The second part, the research methodology, explains the 
process of a journal article search. The third part presents research findings and discussions relating to the findings analysis. The fourth part contains the conclusion, limitation, and future research.

\section{Research methodology}

With this study, the authors intend to provide an overview of the literature on the development of network research in public administration studies over the 10-year period of 2007-2016 through a literature review. Specifically, the authors searched articles on this topic from respected peer-review journals in three search stages.

\section{Stage 1: Data Source and Document Selection}

The first stage entailed searching the 2015 SCImago Journal Rankings (SJR) issued by Scopus considering that Scopus offers free journal searching and has the largest database of peer-reviewed literature and abstracts (Leydesdorff et al., 2010). The SJR ranks journals by what it calls their "average prestige per article". The articles are ranked based on numbers of citations and the prestige of the journals the articles are published in; articles in journals with higher prestige are given higher prestige rankings. The SJR index began in 1996.

Scopus ranks journal prestige by quartile, where journals with the best reputations and quality are placed in Quartile 1 (Q1, excellent), and others are placed in Q2, Q3, or Q4 based on reputation. The search for literature on networks in public administration journals resulted in 111 journals, 28 of which were ranked in Q1.

The authors then divided these 28 journals into three regions, the United States (10) and Europe (18); there were no Q1-ranked journals in Asia in this research category. The authors then selected five journals each from the United States and Europe. Because there were no Q1 journals in Asia, the authors broadened the search and identified two public administration journals, one in Q3 and one in Q4.

\section{Stage 2: Research Terms, Inclusion and Exclusion Process}

In the second stage, based on Wachhaus (2009) - who followed the perspective of Hay and Richards (2000), i.e., that networks are defined by how people talk about them - for this study, the authors searched for articles that contained the key word "network" in titles and abstracts, specifically by examining each issue of each journal for each year of the study period (i.e., 2007-2016). In order to cross-check for articles containing the word "network" that might have been left out, the authors also conducted automatic searches on each journal's website.

\section{Stage 3: Analysis and presentation of results}

In the third stage, the authors thoroughly read each article and then classified them based on topic, methodology, and area coverage. The articles were then analyzed and categorized into major topic areas based on the findings. 


\section{Results and discussion}

\section{Developing Networks Research}

Isett et al. (2011) define research on networks in public administration "as still in early stages", which suggests that there are still challenges and fundamental questions that require addressing, particularly how different networks research phenomena can be explained (ibid., p. 160). Numerous scholars have conducted efforts to orient network research using universal language to facilitate the collective endeavors of scholars to understand the concept of networks in public administration studies.

However, the above undertakings fall far short of expectations for network research in public administration studies in terms of producing a standard for conducting assessments. This is in stark contrast to network research in sociology, which has been developing for over 50 years based on the now standard concepts of centrality, density, cohesion, and betweenness (Freeman, 1997; 1999 in Wachhaus, 2009). Rhodes even classified the analysis of the network approach in sociology and political science into three levels - micro, meso, and macro (Rhodes, 1990, p. 294).

The search for articles from the 12 selected journals resulted in 216 research articles on networks in public administration. Figure 1 illustrates the fluctuations in research on the topic during the study period.

\section{Figure 1: Numbers of articles on networks published in 2007-2016}

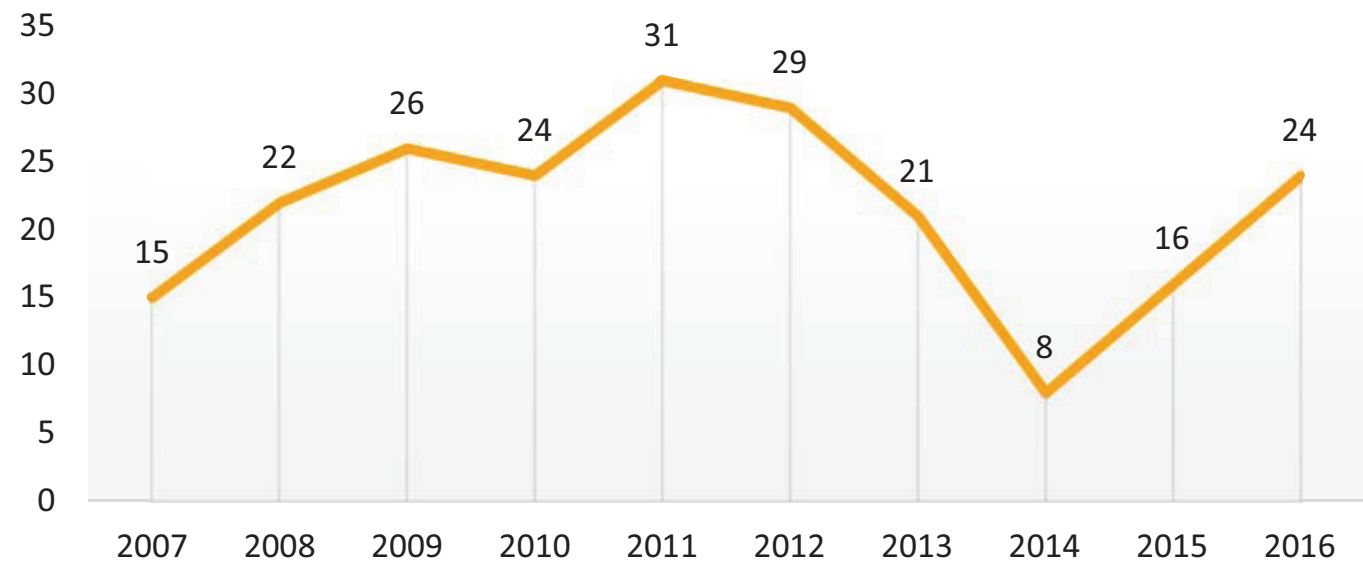

Wachhaus (2009) conducted a literature survey on network research in the top ten public administration journals and observed an increase in network research in the years 2000 and 2003 as well as a sharp increase in 2006. Figure 1 reflects similar results: network research increased steadily until 2011, decreased sharply in 2014, and increased again in 2015 and 2016. It should be highlighted that the distribution of network articles in the 12 journals was unequal, as displayed in Table 1. 
Table 1

\section{Numbers of articles on networks by journal}

\begin{tabular}{|l|c|}
\hline \multicolumn{1}{|c|}{ Name of Journal } & Number of Articles \\
\hline Administrative Science Quarterly & 21 \\
\hline Journal of Policy Analysis and Management & 5 \\
\hline American Review of Public Administration & 19 \\
\hline International Public Management Journal & 13 \\
\hline Administration and Society & 11 \\
\hline Journal of Public Administration Research and Theory & 29 \\
\hline Public Administration Review & 21 \\
\hline Journal of European Public Policy & 17 \\
\hline Public Administration & 43 \\
\hline Policy Studies Journal & 23 \\
\hline International Review of Public Administration & 12 \\
\hline Frontiers of Business Research in China & 2 \\
\hline
\end{tabular}

The distribution of articles was interesting to observe. In general, Public Administration had the most articles, and among the 12 journals, only Public Administration and the Journal of European Public Policy published network research articles annually; the authors assume that the inconsistent numbers of articles have contributed to the fragmentation in the concept of networks in public administration. Wachhaus (2009) found only one researcher who had consistently focused on networks research with 11 published articles; meanwhile, between 1987 and 2006, many researchers only published one article on networks. This led Hummel (2007) in Catlaw $(2009$, p. 480$)$ to say that "there has been a problematic convergence of public administration thought around networks".

\section{Variations of Network Research}

For this article, the authors mapped the network literature by dividing articles by topic and methodology.

\section{- Topic}

Network research in public administration has been developing rapidly based on the variety of topics that emerged in the period 2007-2016: general attributes of networks (Wachhaus, 2009); governance networks (Catlaw, 2009; Zeemering, 2012; Ha \& Felock, 2012; Casey, 2015; Klijn \& Skelcher, 2007; Hendricks, 2008; Sorensen \& Torfing, 2005; Klijn, Steijn \& Edelenbos; 2010); policy networks (Greenaway, Salter \& Hart; 2007; Bevir \& Richards, 2009; Marsh et al., 2009; Wilkinson, Lowe \& Donaldson, 2010; Pedersen, 2010; Zheng, Jong \& Koppenjan, 2010; Toke, 2010; Bax, Jong \& Koppenjan; 2016, Tomlinson, 2010); knowledge networks (Dawes \& Schneider, 2007; Scharf, Laze \& Mergel, 2012; Lee, 2013); trust in net- 
works (Limbright, Mischen \& Laramee, 2009); network performance (Herranz, 2010; Span et al., 2012; Owens \& Acevedo, 2012; Akkerman, Torenvlied \& Schalk, 2012; Kenis \& Provan, 2009); social networks (Lee \& Kim, 2011; Peverelli et al., 2011; Wang \& Gao, 2011); emergency management networks (Kapucu \& Garayev, 2013, 2016); and networking behavior (Walker, O’Toole, \& Meier, 2007).

The authors then categorized the research topics based on the three streams identified by Isett et al., (2011): policy, collaborative, and governance networks.

Policy Networks. The concept of policy networks initially focused on allocation of public resources in policy making (Isett et al., 2011, p. i158). According to Laumann and Knoke (1987), policy networks have a "shared fate" between public organizations, legislative bodies, and interest groups that are interconnected and have their own respective interests in policy making (see: Isett et al., 2011, p. i158).

Governance Networks. The second stream of network research focuses on inter-organizational coordination in accomplishing common objectives derived from networks themselves (Isett et al., 2011).

Collaborative Networks. The third stream of network research focuses on provision of goods and services through collaborations between government institutions and for-profit and nonprofit organizations. This provision requires collaboration among actors, particularly when one actor is unable and unwilling to create and produce goods and services in the required amount (Agranoff and McGuire, 2003; Isett et al., 2011). Table 2 presents the results of this categorization by stream.

\section{Table 2}

Network research topic classification based on Isett et al., 2011

\begin{tabular}{|l|c|c|c|}
\hline \multicolumn{1}{|c|}{ Name of Journal } & \multicolumn{2}{|c|}{ Topic } \\
\hline Administrative Science Quarterly & $\begin{array}{r}\text { Policy } \\
\text { Network }\end{array}$ & $\begin{array}{c}\text { Governance } \\
\text { Network }\end{array}$ & $\begin{array}{c}\text { Collaborative } \\
\text { Network }\end{array}$ \\
\hline Journal of Policy Analysis and Management & 0 & 18 & 3 \\
\hline American Review of Public Administration & 3 & 3 & 2 \\
\hline International Public Management Journal & 2 & 15 & 1 \\
\hline Administration and Society & 2 & 10 & 5 \\
\hline Journal of Public Administration Research and Theory & 9 & 5 & 3 \\
\hline Public Administration Review & 1 & 15 & 3 \\
\hline Journal of European Public Policy & 6 & 8 & 4 \\
\hline Public Administration & 17 & 25 & 1 \\
\hline Policy Studies Journal & 18 & 3 & 2 \\
\hline International Review of Public Administration & 2 & 6 & 4 \\
\hline Frontiers of Business Research in China & 0 & 2 & 0 \\
\hline
\end{tabular}

Source: Literature survey results 
The authors found that scholars often did not emphasize which stream their work fit into, which made it difficult to categorize some of the articles, and this has been a common limitation regarding the three streams. Borzel (1998) in Isett et al., (2011) notes that although scholars have conducted studies within the three streams, many are still uncertain about how to apply the streams.

One interesting topic that emerged during the searches for this literature review was "dark side" networks; three of the 216 articles reviewed these networks, specifically, terrorist networks (Bakker, Raab \& Milward, 2012; Gardeazabal \& Sandler, 2015) and corrupt government (Jancsics \& Javor, 2012). Bakker et al. (2012) specifically discussed this in their article entitled A Preliminary Theory of Dark Network Resilience, which reports on how to address international crime and terrorist networks, and Gardeazabal and Sandler (2015) examined the role of Interpol in monitoring terrorist networks. Jancsics and Javor (2012) analyzed networks for perpetrating criminal acts within governments.

These authors all used case study methodology in their research. Although research on dark side networks presents them as dangerous and having negative connotations, in the context of the concept of networks, dark networks are seen as a metaphor.

\section{- Methodology}

The methodology authors use is one determining factor in understanding whether there is a consensus on the concept and definition of networks in public administration studies. Methodology determines the kinds of results authors intend to attain. Every methodology bears its advantages and disadvantages respectively. The network research conducted by public administration scholars show that in relation to the use of methodology, the majority of them still rely on qualitative and quantitative methodologies. Table 3 presents the methodologies used in the research articles identified for this literature review in the period 2007-2016.

Table 3

Methodologies in networks research

\begin{tabular}{|l|c|c|c|}
\hline \multicolumn{1}{|c|}{ Name of Journal } & \multicolumn{3}{|c|}{ Methodology } \\
\hline Administrative Science Quarterly & Qualitative & Quantitative & Mix \\
\hline Journal of Policy Analysis and Management & 2 & 19 & 0 \\
\hline American Review of Public Administration & 1 & 4 & 0 \\
\hline International Public Management Journal & 8 & 10 & 1 \\
\hline Administration and Society & 6 & 7 & 0 \\
\hline Journal of Public Administration Research and Theory & 11 & 3 & 1 \\
\hline
\end{tabular}




\begin{tabular}{|l|c|c|c|}
\hline Public Administration Review & 14 & 7 & 0 \\
\hline Journal of European Public Policy & 11 & 3 & 4 \\
\hline Public Administration & 36 & 7 & 0 \\
\hline Policy Studies Journal & 11 & 9 & 3 \\
\hline International Review of Public Administration & 7 & 5 & 0 \\
\hline Frontiers of Business Research in China & 1 & 1 & 0 \\
\hline
\end{tabular}

Source: Literature survey results

The use of quantitative methodology reflects scholars' intent to provide more objective results within network research. Authors denote the limitations in their research that make it necessary to use caution in generalizing their results regarding theories in public administration network research. Although the aim of this quantitative research has been to provide objective results, there is as yet no consensus on the concept, definition, attributes, and standard of measures of networks in public administration (Blom-Hansen, 1997; Borzel, 1998; Damgaard, 2006; Hall and O'Toole, 2002, 2004; Wachhaus, 2009; Isett et al., 2011; Lecy, Mergel \& Schmitz, 2014), leading Catlaw (2009, p. 480) to conclude that "networks have been accepted uncritically in public administration without any examination of their underpinnings".

A number of journals even demand research results to be published in the form of a journal article and empirical data to be used quantitatively, and even the data and data analysis results stage to be published along with the article (Isett et al., 2011). Furthermore, Isett et al. mention that it is high time that journals in the field of public administration do the same.

"Steps such as these would begin to allow our field to build a broader understanding of network (and other) phenomena without the expense of extensive data collection by making existing datasets more readily available" (ibid., p. i167)

Previous research carried out by Iset et al., (2011) and Kapucu, Hu and Hosa (2017) recommend scholars studying network research in public administration to employ a mix method in data collection. Kapucu, Hu and Hosa (2017, p. 1110) state "Future research designs should continue using multiple types of data collection methods to overcome the constraints of one method". A mix method is a vital necessity in network research within public administration study wherein reliability and validity can possibly be improved (Kapucu, Hu \& Hosa, 2017, p. 1110). The results of research conducted by Kapucu, Hu and Hosa in analysing 81 SNA articles in public administration show an increase in the use of hybrid data collection methodology in network research. The number is, however, still very limited and it has yet to experience the increases that qualitative and quantitative have. Ultimately, the results of this study show similar findings to those conducted by previous researchers in the period of 2007-2016. In relation to the use of methodology, researchers have yet to combine quantitative and qualitative data collection when conducting networks research as shown in Table 3. 
Technical expertise in statistical networks is very much needed bearing in mind that the continuity of networks research depends on the clarity of a definition of networks and related measures (Wachhaus, 2009; Lecy, Mergel \& Schmitz, 2014). "Public administration scholars need to foster closer ties with technical disciplines that are developing new methods and measures" (Isett et al., 2011, p. i168). In one of its editions, the Policy Studies Journal offers scholars an opportunity to explore networks from a technical point of view, and authors appear to consistently use social network analysis for exploring networks. Authors use measures that are common in sociology such as density and centrality. The use of concepts, measures and theories from other scientific disciplines stresses that public administration is a multidisciplinary field (Rainey, 1994) that cannot stand alone as a typical science (Kuhn, 1962 in Ricucci, 2010).

\section{Definitions of Networks in Public Administration Research}

There is currently no general definition of networks (Agranoff \& McGuire, 2001; Borzel, 1998; O’Toole, 1997 in Wachhaus, 2009, pp. 60-61), and Wachhaus (2009) observed that there are no generally accepted attributes of networks (2009, p. 67). Meanwhile, the continuity of network research in the future will be significantly determined by the clarity of concept and definition of networks in itself.

"Network research in public administration has come a long way, but future progress in sustaining this vibrant research agenda depends on increased conceptual and definitional clarity" (Lecy et al., 2014, p. 657).

Why is consensus on a concept of utmost importance? A theory is considered a theory when it applies generally and explains various objects (Dowding, 1995). This leads us to revisit the question of whether there is a consensus on the paradigm used and applied in public administration. Referring to Thomas Kuhn's pattern stating that a paradigm is determined by the commitment/consensus of scholars in an academic community, within that community there is a division of commitment among the members with mutual conviction to reconstruct theories, epistemologies, and methodologies within the limitation of their scientific discipline (Ricucci, 2010; Sutarna et al., 2017). According to Kuhn, a paradigm is a framework theory and paradigm is essential to scientific inquiry and progress (1970, p. 10-76).

Based on Kuhn's pattern which requires the mutual commitment of public administration scholars on the general definition of network, and upon observation of literature survey results of network articles in public administration journals, it can thus be said that since the initial development of network research up until now, there is yet to be a consensus agreeing upon the definition of network in public administration. Therefore, clarity on the concept of network has not been reached as of yet. Such failure in reaching a consensus may be attributed to each scholar having differing perspectives and approaches in studying public administration (Riccucci, 2010). How scholars understand and utilize network are, hence, dependent on the perspectives and approaches they use.

Aside from the unavailability of consensus on the definition/concept of network, the literature survey results found several usages of the term "networks" 
in research that scholars often use. Table 4 presents some of the current usages of the term "networks" in public administration studies.

\section{Table 4}

\section{Usages of the term "networks" in public administration research}

\begin{tabular}{|c|c|}
\hline \multicolumn{2}{|r|}{ NETWORK } \\
\hline $\begin{array}{l}\text { As a panacea in resolving issues confronted } \\
\text { by policy and public management }\end{array}$ & Adam \& Kriesi (2007) \\
\hline As a different political collectivity & Catlaw (2009) \\
\hline A Metaphor & $\begin{array}{l}\text { Catlaw (2009) } \\
\text { Dowding (1995) }\end{array}$ \\
\hline Are Forms of governance & Park \& Park (2009) \\
\hline As a tool of public management & Eglene, Dawes \& Schneider (2007) \\
\hline As code sharing & Catlaw (2009) \\
\hline $\begin{array}{l}\text { As Complex Interaction setting for solving } \\
\text { problems }\end{array}$ & $\begin{array}{l}\text { Sorensen \& Torfing (2007) } \\
\text { Scharpf (1978) } \\
\text { Agranof \& McGuire (2001) }\end{array}$ \\
\hline A new paradigm of public administration & Greer (2002), Raab \& Milward (2003) and Goerdel (2006), \\
\hline $\begin{array}{l}\text { As catalyst in transforming notion of gov- } \\
\text { ernance }\end{array}$ & $\begin{array}{l}\text { Goodsell (2006), Peters (1998), Rhodes (1996) and So- } \\
\text { rensen (2006) }\end{array}$ \\
\hline $\begin{array}{l}\text { New approaches to understanding policy } \\
\text { process }\end{array}$ & $\begin{array}{l}\text { Bressers \& O’Toole (1998), Marsh (1998) Sabatier \& } \\
\text { Jenkins-Smith(1998) }\end{array}$ \\
\hline As tools of organization analysis & Cross (2004) \\
\hline
\end{tabular}

Source: Adopted and summarized from previous research results and recommendations.

Of the numerous understandings on networks, Isett et al. (2011, p. i160-i161) divide the use of the term "networks" in public administration studies into three perspectives: network as a metaphor or an organizing concept; network as a method or methodological paradigm; and network as an approach to or a tool for understanding public service provision.

1) Network as a metaphor or an organizing concept. The concept of network as a metaphor is a very useful and powerful means of understanding social phenomena in their contexts. Catlaw (2009, p. 478) states that "one of the most powerful and ubiquitous metaphors today is the network," and Pardomuan (2006) finds that policy networks are metaphorical in nature. Actors create pseudo policy communities and design elitist conditions during policy formulation based on the authority they possess.

2) Network as method or methodological paradigm. Social network analysis is common in the literature and, according to Isett et al. (2011), focuses on developing tools, refining measures, and using terms appropriately in order to establish a standard measure for networks. 
3) Network as an approach to or a tool for understanding public service provision. The perspective of networks is an approach to understanding how networks operate in creating and providing coordinated services, and according to Isett et al. (2011), the perspective focuses on formal networks.

Upon reading the literature, the authors have summarized network research results in public administration to be distributed into stream, functions, perspective, and actor relations as described in Table 5.

Table 5

\section{Streams, Functions, and Perspectives of Networks in Public Administration}

\begin{tabular}{|l|l|l|l|}
\hline \multicolumn{1}{|c|}{ Stream } & \multicolumn{1}{|c|}{ Functions } & \multicolumn{1}{|c|}{ Perspective } & \multicolumn{1}{|c|}{ Relations } \\
\hline - Policy Networks & - Coordination & - As a metaphor/ an organiz- & - Formal \\
- Governance Networks & - Collaboration & ing concepts & - Informal \\
- Collaborative Networks & - Cooperation & $\begin{array}{l}\text { - Method/ methodological } \\
\text { paradigm } \\
\text { - approach to or a tool for } \\
\text { understanding public service } \\
\text { provision }\end{array}$ & \\
& & & \\
\hline
\end{tabular}

Source: Modification from various sources.

The findings of this literature review research have provided future direction that might be useful for the field of public administration. The discourse on networks in public administration discipline is important in terms of taking stock of the policy process and whether a more fundamental theory is required. In this review, we argue that whilst we have learned much about usage, topics, stream and methodologies of the network research, policy network analysis began only as a metaphor and may only become a theory by developing along the lines of sociological network analysis (Dowding, 1995).

This article makes it clear that the differences between concepts of network are never-ending from most perspectives. There is less need for discussion of the configuration of networks. The continuity of network research does not depend on clarity and definition of the concept of network in itself. All the usage of the networks terms are meaningful and provide the networks landscape. However, the implications of networks differ depending on how they are conceptualized and studied. This is quite apparent from the constant rise in network research in various fields. Furthermore, even traditional public administration theory still has much to offer to the study and analysis of networks. Network analysis studies will become an increasingly important issue for the future because it requires people working in government and administration to think of organization as an external internal activity. The rise of networks as an emerging institution has integrated a predominantly rationalistic actor approach with cognitive approaches based on public administration theory.

The contribution of this study is based on the fact that the field of public administration needs to be more aware of the network literature in other disciplines and to employ this research to advance the understanding of network issues in the public sector context. 


\section{Conclusion}

There is no denying that public administration scholars are very interested in network research, as indicated by the steady annual increase in networks research articles, and a number of conclusions can be drawn.

First, the topics in network research exceed any ability to cluster them because of the overlap between different topic clusters or streams. In addition, the limits of specific clusters are unclear. This is not unlike public administration itself, which continues to develop based on the complexities of public issues.

Second, from a methodological aspect, the use of hybrid methodology is much needed to acquire both quantitative and qualitative data with the aim of one methodology covering the imperfections of the other.

Third, differences in approaches and perspectives public administration scholars use in understanding networks have implications on the heterogeneity of network research. Such differences subsequently affect the way they define network. The increasing number of research and differences in using the "term" network indicates that clarity on the concept of network has yet to be reached. Additionally, it is also shown that there is no consensus regarding the concept of network that is agreed upon by scholars when referring to Kuhn's pattern.

Fourth, the emergence of new topics such as dark side networks and statistical model networks is expected to enrich the body of literature on networks in public administration. Scholars need not feel limited by the issue of "borrowing" theories from fields other than public administration as long as the intent is to resolve public matters.

This research has a number of limitations. The articles obtained from 12 Public Administration journals, totalling 216 articles, cannot yet represent network research in this study. This research merely dissected the journals based on ranking and countries handling the journals. Therefore, the acquired results cannot generalize the findings entirely and they do not represent the regions as the distribution was based on journals and not cases occurring in the regions. Future studies conducting a systematic literature review should conduct a survey of all network research journal articles in all journals at every ranked level of public administration journals or even in all journals at all levels in order to produce more comprehensive results. A survey of journal articles should be conducted across various scientific disciplines bearing in mind that public administration is multidisciplinary in nature. The division of a network stream into three categories has yet to produce a clear concept on the differences of each category, instead resulting in confusion among scholars in the network stream they study. It would, thus, be fascinating to further analyse the differences between the three network streams.

\section{Declaration of Conflicting Interests}

The author(s) declared no potential conflicts of interest with respect

to the research, authorship, and/or publication of this article. 


\section{REFERENCES}

1. Adam, S. \& Kriesi, H. (2007). The network approach. In: Theories of the Policy Process $2^{\text {th }}$. Edited by P. Sabatier. Boulder CO: Westview Press.

2. Agranoff, R. (2007). Managing within networks: Adding value to public organizations. Washington, D.C.: Georgetown University Press.

3. Agranoff, R. \& McGuire, M. (2001). Big Questions in Public Network Management Research. Journal of Public Administration Research and Theory. J-PART, vol. 11, no 3, pp. 295-326.

4. Akkerman, A., Torenvlied, R. \& Schalk, J., (2012). Two-Level Effects of Interorganizational Network Collaboration on Graduate Satisfaction. A Comparison of Five Intercollege Networks in Dutch Higher Education. American Review of Public Administration, vol. 42, no 6, pp. 654-677.

5. Bakker, R.M., Raab, J. \& Brinton, M. H. (2012). A Preliminary Theory of Dark Network Resilience. Journal of Policy Analysis and Management, vol. 31, no 1, pp. 33-62.

6. Bax, C., Jong, M. De. \& Koppenjan, J. (2010). Implementing Evidence Based Policy in a Network Setting. Road Safety Policy in the Netherlands. Public Administration, vol. 88, no 3, pp. 871-884.

7. Blom, H. J., (1997). A New Institutional Perspective on Policy Networks, Public Administration, vol. 75, pp. 669-693.

8. Bogason, P. \& Toonen, T. A. J. (1998). Introduction: Networks in Public Administration. Public Administration, vol. 76, pp. 205-227.

9. Borzel, T. (1998). Organizing Babylon- On the Different Conceptions of Policy Networks. Public Administration, vol. 76, pp. 253-273.

10. Bevir, M. \& Richards, D. (2009). Decentering Policy Networks: A Theoretical Agenda. Public Administration, vol. 87, no 1, pp. 3-14.

11. Casey, C. (2015). Public Values in Governance Networks Management Approaches and Social Policy Tools in Local Community and Economic Development. American Review of Public Administration, vol. 45, no 1, pp. 106-127.

12. Catlaw, T.J. (2009), Governance and Networks at the Limits of Representation. American Review of Public Administration, vol. 39, no 5, pp. 478-498.

13. Damgaard, N. (2006). Do Policy Networks Lead to Network Governing? Public Administration, vol. 84, no 3, pp. 673-691.

14. Dawes, O., E.S.S. \& Schneider, C. A. (2007). Authority and Leadership Patterns in Public Sector Knowledge Networks. American Review of Public Administration, vol. 37, no 1, pp. 91-113.

15. Dowding, K. (1995). Model or Metaphor? A Critical Review of the Policy Network Approach. Political Studies, vol. XLIII, pp. 136-158.

16. Eglene, O., Dawes, S.S., Schneider, C. A. (2007). Authority and Leadership Patterns in Public Sector Knowledge Networks. The American Review of Public Administration, vol. 37, no 1, pp. 91-113. 
17. Freeman, L. S. (1977). A Set of Measures of Centrality Based on Betweenness. Sociometry, vol. 40, no 1, pp. 35-41.

18. Freeman, L. S. (1979). Centrality in Social Networks: Conceptual Clarification. Social Networks, vol. 1, pp. 215-239.

19. Gardeazabal, J., Sandler, T. (2015). INTERPOL's Surveillance Network in Curbing Transnational Terrorism. Journal of Policy Analysis and Management, vol. 34, no 4, pp. 761-780.

20. Ha, H. \& Feiock, R. C. (2012). Bargaining, Networks, and Management of Municipal Development Subsidies. American Review of Public Administration, vol. 42, no 4, pp. 481-497.

21. Hall, T. \& O’Toole, L. (2004). Shaping Formal Networks through the Regulatory Process. Administration and Society, vol. 36, no 2, pp. 186-207.

22. Hay, C. \& Richards, D. (2000). The Tangled Webs of Westminster and Whitehall: The Discourse, Strategy and Practice of Networking within the British Core Executive. Public Administration, vol. 78, no 1, pp. 1-28.

23. Hendriks, C. M. (2008). On Inclusion and Network Governance: The Democratic Disconnect of Dutch Energy Transitions. Public Administration, vol. 86, no 4, pp. 1009-1031.

24. Herranz, J. (2010). Multilevel Performance Indicators for Multisectoral Networks and Management. American Review of Public Administration, vol. 40, no 4, pp. 445-460.

25. Hummel, R, (2007). What do theorists do? Administrative Theory \& Praxis, no 29, pp. 292-296.

26. Isett, K.R. et. al. (2011). Networks in Public Administration Scholarship: Understanding Where We Are and Where We Need to Go. Journal Public Administration Research and Theory, vol. 21, suppl. 1, pp. i157-i173.

27. Jancsics, D. \& Jávor, I., (2012). Corrupt Governmental Networks. International Public Management Journal, vol. 15, no 1, pp. 62-99. Available at: http://dx.doi.org/10.1080/10967494.2 012.684019 (accessed: 25 January, 2019).

28. Greenaway, J., Salter, B. \& Hart, S. (2007). How Policy Networks Can Damage Democratic Health: A Case Study in The Government of Governance. Public Administration, vol. 85, no 3, pp. 717-738.

29. Kapucu, N. \& Garayev, V. (2013). Designing, Managing and Sustaining Functionally Collaborative Emergency Management Networks. American Review of Public Administration, vol. 43, no 3, pp. 312-330.

30. Kapucu, N. \& Garayev, V. (2016). Structure and Network Performance Horizontal and Vertical Networks in Emergency Management. Administration and Society, vol. 48, no 8, pp. 931-961.

31. Kapucu, N., Hu, Q. \& Khosa, S. (2017). The State of Network Research in Public Administration. Administration \& Society, vol. 49, no 8, pp. 1087-1120.

32. Kenis, P. \& Provan, K. G. (2009). Towards an Exogenous Theory of Public Network Performance. Public Administration, vol. 87, no 3, pp. 440-456.

33. Klijn, E. H. \& Skelcher, C. (2007). Democracy and Governance Networks: Compatible or Not? Public Administration, vol. 85, no 3, pp. 587-608.

34. Klijn, E. H., Edelenbos, J. \& Steijn, B. (2010). Trust in Governance Networks: Its Impact on Outcomes. Administration and Society, vol. 42, no 2, pp. 193-221. 
35. Kuhn, T. S. (1962). The structure of scientific revolutions. Chicago: University of Chicago Press. In: Ricucci, N.M. (2010). Public Administration: Traditions of Inquiry and Philosophies of Knowledge. Washington, D.C. USA: Georgetown University Press.

36. Kuhn, T.S. (1970). The structure of scientific revolutions. 2nd Edition, Chicago : University of Chicago Press

37. Lambright, K. T., Mischen, P. A. \& Laramee, C. B. (2009). Building Trust in Public and Nonprofit Networks Personal, Dyadic and Third-Party Influences. American Review of Public Administration, vol. 40, no 1, pp. 64-82.

38. Laumann, E. O. \& Knoke, D. (1987). The organizational state. Madison, WI: University of Wisconsin Press.

39. Lee, J. (2013). Exploring the Role of Knowledge Networks in Perceived e-Government. A Comparative Case Study of Two Local Governments in Korea. American Review of Public Administration, vol. 43, no 1, pp. 89-108.

40. Lee, J. \& Soonhee, K. (2011). Exploring the Role of Social Networks in Affective Organizational Commitment: Network Centrality, Strength of Ties, and Structural Holes. American Review of Public Administration, vol. 41, no 2, pp. 205-223.

41. Lecy, J. D., Mergel, I. A. \& Schmitz, H. P. (2014). Networks in Public Administration: Current Scholarship in Review. Public Management Review, vol. 15, no 5, pp. 643-665.

42. Leydesdorff, L., De Moya-Anegón, F. \& Guerrero-Bote, V. P. (2010). Journal Maps on the Basis of Scopus Data: A Comparison with the Journal Citation Reports of the ISI. Journal of the American Society for Information Science and Technology, vol. 61, no 2, pp. 352-369. Available at: https://arxiv.org/ftp/arxiv/papers/0909/0909.3193.pdf (accessed: 25 January, 2019).

43. Marsh, D. et al. (2009). Policy Network and the Distinction between Insider and Outsider Groups: The Case of the Countryside Alliance. Public Administration, vol. 87, no 3, pp. 621-638.

44. Marsh, D. \& Rhodes, R.A.W. (eds.) (1992). Policy Networks in British Government. Oxford: Oxford University Press.

45. Muller, S.D. (2015). Success Factors Influencing Implementation of e-government at Different Stages of Maturity: A Literature Review. International Journal of Electronic Governance. Available at: DOI: 10.1504/IJEG.2015.069495, https://www.researchgate.net/publication/277905682 (accessed: 25 January, 2019).

46. O’Toole, L. J. (1997). Treating Network Seriously: Practical and Research Based Agendas in Public Administration. Public Administration Review, vol. 57, pp. 45-52.

47. Owens, C. T. \& Acevedo, S. K. (2012). Network Diversity and the Ability of Public Managers to Influence Performance. American Review of Public Administration, vol. 42, no 2, pp. 226-245.

48. Pardomuan, R. A. (2006). Jejaring Kebijakan pada Proses Penyusunan dan Penetapan Rencana Tata Ruang Wilayah Kota Padang Tahun 2004-2013. Tesis. UGM

49. Pedersen, A. B. (2010). The Fight over Danish Nature: Explaining Policy Network Change and Policy Change. Public Administration, vol. 88, no 2, pp. 346-363.

50. Pesch, Udo. (2005). The Predicaments of Publicness: An Inquiry Into The Conceptual Ambiguity of Public Administration. Available at: https://www.researchgate.net/publication/37721641 (accessed: 25 January, 2019). 
51. Peverelli, P. J, Song, L. Jiwen, Sun, Zhiqiang \& Yu, Jianfeng (2011). Extending Network Analysis with Social Inclusions: A Chinese Entrepreneur Building Social Capital, Front. Bus. Res. China, vol. 5, no 1, pp. 121-143.

52. Rhodes, R. A. W. (1990). Policy Networks: A British Perspective, Journal of Theoretical Politics, vol 2, no 3, pp. 293-317.

53. Ricucci, N. M. (2010). Public Administration: Traditions of Inquiry and Philosophies of Knowledge. Washington, D.C., USA: Georgetown University Press.

54. Span, Kees C. L. et. al. (2012). The Relationship Between Governance Roles and Performance in Local Public Interorganizational Networks A Conceptual Analysis, American Review of Public Administration, vol. 42, no 2, pp. 186-201.

55. Binz-Scharf, M. C., Lazer, D. \& Mergel, I. (2012). Searching for Answers Networks of Practice Among Public Administrators. American Review of Public Administration, vol. 42, no 2, pp. 202-225.

56. Sir Thomson, G. (1961). The Inspiration of Science. In: Wachhaus, A. (2009) (ed.) Networks in Contemporary Public Administration: A Discourse Analysis, Administrative Theory \& Praxis, vol. 31, no 1, pp. 59-77.

57. Sorensen, E. \& Torfing, J. (2009). Making Governance Networks Effective and Democratic Through Meta Governance. Public Administration, vol. 87, no 2, pp. 234-258.

58. Sutarna, Iwan Tanjung; Husna, Khuriyatul \& Iswari, Paramita (2017). Elaboration on Public Administration Crises: An Endeavor in Seeking Scientific Identity. Policy \& Governance Review, vol. 1, no 1, pp. 12-25 (doi: https://doi.org/10.30589/pgr.v1i1.21).

59. Tomlinson, I. J. (2010). Acting Discursively: The Development щf UK Organic Food and Farming Policy Networks. Public Administration, vol. 88, no 4, pp. 1045-1062.

60. Toke, D. (2010). Politics by Heuristics: Policy Networks with a Focus on Actor Resources, as Illustrated by the Case of Renewable Energy Policy under New Labour. Public Administration, vol. 88 , no 3 , pp. $764-781$.

61. Wachhaus, A. (2009). Networks in Contemporary Public Administration: A Discourse Analysis. Administrative Theory \& Praxis, vol. 31, no 1, pp. 59-77.

62. Wang, Qin \& Gao, Shanxing (2011). Network Architecture and Firm Performance: A Resources-Based View. Front. Bus. Res. China, vol. 5, no 4, pp. 559-579.

63. Walker, R. M., O’Toole, L. J. \& Meier, K. J. (2007). It's where you are that matters: The Networking behaviour of English local government officers. Public Administration, vol. 85, no 3, pp. 739-756.

64. Webster, J. \& Watson, R. (2002). Analyzing the Past to Prepare for the Future: Writing a Literature Review. MIS Quarterly, vol. 26, no 22, pp. xiii-xxiii.

65. Wilkinson, K., Lowe, P. \& Donaldson, A. (2010). Beyond Policy Networks: Policy Framing and the Politics of Expertise in the 2001 Foot and Mouth Disease Crisis. Public Administration, vol. 88, no 2, pp. 331-345.

66. Zeemering, E. S. (2012). The Problem of Democratic Anchorage for Interlocal Agreements. American Review of Public Administration, vol. 42, no 1, pp. 87-103.

67. Zheng, H., Jong, M.D. \& Koppenjan, J. (2010). Applying Policy Network Theory to Policy Making in China: The Case of Urban Health Insurance Reform. Public Administration, Vol. 88, no 2, pp. 398-417. 